Check for updates

The BMJ

kabbasi@bmi.com Follow Kamran on Twitter@KamranAbbasi Cite this as: BMJ 2021;375:n2607 http://dx.doi.org/10.1136/bmi.n2607 Published: 28 October 2021

\section{Memo to COP26 leaders: abandon your hubris, politics, and pride and see the future through young people's eyes}

\section{Kamran Abbasi executive editor}

“Don’t let anybody else decide your future,” Barack Obama urged young people this week. "Imagine a better future and help make it real.” In fairness, young people aren't the problem. The future, unfortunately, is controlled by their parents and grandparents, too many of whom see the future as an only slightly less rosy version of the past. Yet the multiverse of crises we face today won't magically disappear with the click of a superhero's fingers.

Growing numbers of doctors, young and old, are becoming climate activists, joining groups such as Extinction Rebellion to bring about climate policies that will preserve the planet for future generations (doi:10.1136/bmj.n2565). ${ }^{1}$ The political will to agree and implement those policies will be tested at the 2021 United Nations Climate Change Conference (COP26) in Glasgow from 31 October to 12 November. Any attempt to water down commitments on climate will be greater "acts of criminality" than the non-violent protests of climate activists.

Evidence for the effects of climate change on health continues to mount. An ingenious study by Canadian researchers supports a direct relation between particulate air pollution, in the form of PM2.5 concentrations, and death (doi:10.1136/bmj.n2368). ${ }^{2}$ Five year mortality in people who moved from highly polluted to less polluted areas fell by up to $13 \%$. The reverse effect was seen in people who moved to more highly polluted areas. The study isn't a randomised controlled trial, nor does it have perfect observational design; but, with high quality data collection and propensity score matching in a large population, this is the best answer to the question yet and may be hard to improve on (doi:10.1136/bmj.n2561). ${ }^{3}$

Most people, however, are unable to choose the adaptive option of moving house, which increases the onus on $\mathrm{COP} 26$ to find urgent solutions to reduce PM2.5 levels. Many places in the world with the highest PM2.5 levels are also urban areas vulnerable to the health risks of extreme heat

(doi:10.1136/bmj.n2467). ${ }^{4}$ Even in Europe the heatwave of 2003 resulted in 70 ooo excess deaths; and heat related deaths, primarily from "urban heat islands," will increase by a factor of 50 by 2100 (doi:10.1136/bmj.n2438). ${ }^{5}$

Regions of high particulate air pollution and extreme heat are also affected by vaccine injustice-the gross inequity worldwide in vaccine supply and manufacture. Responsibility again rests with leaders of rich countries, to release vaccine technology transfer from the firm grip of corporations and national interests. If countries that make vaccines will inevitably think of themselves first, then the only solution is to ensure that manufacturing capability exists in as many countries as possible in each region (doi:10.1136/bmj.n2375). ${ }^{6}$

Inequalities lie at the heart of crisis after crisis, and tackling them must be a priority-for example, in the response to pressures on the UK's NHS

(doi:10.1136/bmj.n2456), ${ }^{7}$ a crisis that politicians seem intent on downplaying just as frontline professionals and patients see the service falling apart (doi:10.1136/bmj.n2590; doi:10.1136/bmj.n2572; doi:10.1136/bmj.n2594). ${ }^{8-10}$ Nor do politicians seem willing to fully accept the role of covid-19 (doi:10.1136/bmj.n26o6; doi:10.1136/bmj.n2597; doi:10.1136/bmj.n2573), ${ }^{11-13}$ and the urgent actions now needed to limit its effects

(doi:10.1136/bmj.n2595). ${ }^{14}$ A new modelling study projects up to 60 ooo deaths from covid-19 over the winter unless vaccine boosters are delivered to vulnerable populations and people older than 50 and transmission is controlled (https://bit.ly/3BhsOcT). ${ }^{15}$ Indeed, a recent government expert review supports the role of airborne transmission and the benefits of mask wearing and improved ventilation (https://bit.ly/3govX). ${ }^{16}$

It's little wonder, then, that by ignoring its own science on covid measures and launching a misguided, ill timed, and damaging war on GPs the government seems to be living in its own "multiverse of madness" (doi:10.1136/bmj.n2570;

doi:10.1136/bmj.n2584; doi:10.1136/bmj.n2587). ${ }^{17-19}$ How can young people rescue the future from this distressing reality? It's precisely this logic that leads health professionals to non-violent activism and dissent. It's the same activism that helped women win the vote and Gandhi create a nation. The onus on world leaders gathering in Glasgow is to abandon their hubris, politics, and pride and instead see the future through young people's eyes.

Wise J. The doctors getting arrested for climate change: a professional duty?BMJ 2021;375:n2565.

2 Chen H, Kaufman JS, Olaniyan T, etal. Changes in exposure to ambient fine particulate matter after relocating and long term survival in Canada: quasi-experimental study. BMJ 2021;375:n2368. doi: 10.1136/bmj.n2368 pmid: 34625469

Pereira G. Cut particulate air pollution, save lives. BM/2021;375:n2561. doi: 10.1136/bmj.n2561 pmid: 34670803

4 Tong S, Prior J, McGregor G, Shi X, Kinney P. Urban heat: an increasing threat to global health. BMJ2021;375:n2467. doi: 10.1136/bmj.n2467 pmid: 34697023

5 Khosla R, Jani A, Perera R. Health risks of extreme heat. BMJ 2021;375:n2438. doi: 10.1136/bmj.n2438 pmid: 34620684

6 Feinmann J. Covid-19: global vaccine production is a mess and shortages are down to more than just hoarding. BMJ 2021;375:n2375.

7 Patel K, Chapman R, Gill R, Richards J. Ensuring an equitable recovery for the NHS. BMJ 2021;375:n2456. doi: 10.1136/bmi.n2456 pmid: 34635565

8 Mahase E. Ambulances queue outside A\&Es as 999 calls pile up. BMJ 2021;375:n2590. doi: 10.1136/bmj.n2590 pmid: 34686478

9 lacobucci G. Covid-19: UK needs more doctors to support post-pandemic recovery, say leaders. BMJ 2021;375:n2572 doi: 10.1136/bmj.n2572 pmid: 34670773 
10 Rimmer A. GPs move towards industrial action after rejecting "rescue plan" for general practice. BM/2021;375:n2594. doi: 10.1136/bmj.n2594 pmid: 34686485

11 Mahase E. Covid-19: NHS Test and Trace failed despite "eye watering" budget, MPs conclude. BMJ 2021;375:n2606

12 Stokel-Walker C. How bad is the UK's covid situation?BMJ 2021;375:n2597.

13 Oliver D. David Oliver: What parliament omitted from its "lessons learnt" on coronavirus. BMJ 2021;375:n2573doi: 10.1136/bmj.n2573 .

14 Salisbury H. Helen Salisbury: When do we switch to plan B?BMJ2021:375:n2595. doi: 10.1136/bmj.n2595 pmid: 34702764

15 Perez-Guzman PN, Imai N, Knock ES, et al. Autumn and winter 2021-2022: potential covid-19 epidemic trajectories. Imperial College London. https://assets.publishing.service.gov.uk/government/uploads/system/uploads/attachment_data/file/1027920/S1386_SPI-M_potentiaL_winter_trajectories_Imperial_College.pdf

16 UK Health Security Agency. The role of face coverings in mitigating the transmission of SARS-CoV-2 virus: statement from the Respiratory Evidence Panel. Oct 2021. https://www.gov.uk/government/publications/face-coverings-and-covid-19-statement-from-an-expert-panel/the-role-offace-coverings-in-mitigating-the-transmission-of-sars-cov-2-virus-statement-from-the-respiratoryevidence-panel.

17 Kar P. Partha Kar: Making sense of the health multiverse. BMJ2021:375:n2570. doi: 10.1136/bmj.n2570 pmid: 34702724

18 lacobucci G. The UK government's covid complacency shows lessons haven't been learned. BMI 2021;375:n2584. doi: 10.1136/bmj.n2584 pmid: 34675007

19 Ham C. There is still time to save the NHS, but time is running out. BMJ2021;375:n2587. doi: 10.1136/bmj.n2587 pmid: 34686492 